teodiceer, siden 1825 suppleret med tilliden til trosbekendelsens ord som mundtligt forplantet gennem historien fra Kristus selv. Kierkegaard stik modsat ved at ignorere historien og gøre op med enhver form for historiefilosofi, herunder Grundtvigs og Hegels beslægtede teodiceer for så blot at postulere kristendommens absolutte sandhed i al sin absurditet og paradoksalitet.

Kierkegaard kan have ret i, at Grundtvigs svar på Lessings spørgsmål er uholdbare - men Kierkegaards eget svar var et ikke-svar. Han flygtede fra heden i 'den gloende ovn' ved at vende ryggen til historien, mens Grundtvig vovede sig ind på historiens kampplads med "Ilden som Ideerne om Menneskeslægten skal gaae igjennem for at bevise deres Byrd".

\title{
Luthertolkningen i 1812-krøniken
}

\section{Af Anders Holm}

Grundtvigs syn på Luthers betydning i Kort Begreb af Verdens Krønike i Sammenhceng svarer på flere måder til det billede, man kan finde senere i forfatterskabet. Det gælder især Grundtvigs overbevisning om reformatorens enestående betydning i historien. Alligevel er portrettet tydeligt bestemt af Grundtvigs verdensbillede i 1812. Det gælder ikke mindst en anderledes vurdering af brugbarheden af Luthers syn på Bibelen, end man finder efter 1825. Grundtvig var dog ikke dermed vendt tilbage til barndomsmiljøernes ældre oplysningsteologi eller en klassisk ortodoksluthersk position, som det af og til er blevet hævdet. Portrætteringen af Luther må i stedet anskues som en del af en kompliceret og original sammentænkning af forsynsteologi og universalhistorie, der ser reformationen og især Luthers indsats med og fortolkning af Bibelen som det foreløbigt mest vellykkede udtryk for Guds vilje med kristendommen i historien.

\section{Baggrunden for Luthertolkningen i VK 1812}

\section{Før 1810}

For at forstå billedet af Luther og lutherdommen i VK 1812 må man gøre sig klart, at den 29-årige Grundtvig befandt sig i et samfund, der var meget forskelligt fra nutidens. Ca. $90 \%$ af befolkningen var bønder, og skønt nye tider var på vej, domineredes enevoldsstaten stadig af en luthersk konfessionskultur ${ }^{1}$ med tæt sammenhæng mellem borgerrettigheder,

\footnotetext{
${ }^{1}$ Begrebet "Konfessionskultur" er inden for nyere tysk kirkehistorisk forskning især blevet udviklet af Olaf Blaschke og Thomas Kaufmann. Udtrykket er en samlebetegnelse for den kulturdannelse, der fandt sted $\mathrm{i}$ århundrederne efter reforma-
} 
katekismeundervisning og statskirkens officielle lære. ${ }^{2}$ Dette ændrer ikke på, at en hel del påstande i 1812-krøniken allerede i samtiden fremstod ejendommeligt forældede, hvad reaktionerne på bogens ankomst vidner om. Men skal man begribe værkets anliggende med Luther som den centrale figur, er man nødt til at være bevidst om denne samfundsmæssige kontekst.

De to præstehjem, Grundtvig voksede op i, var indbegrebet af denne samtidige danske lutherdom. Både hans far, Johan Ottosen Grundtvig, og Laurits Feld i Thyregod, der i årene 1792-98 forberedte ham til Latinskolen, var prægede af den form for oplysningsteologi, der er blevet kaldt supranaturalismen. ${ }^{3}$ Det var en teologi, hvor man forsøgte at sammentænke fornuft og åbenbaring (skriften), om end det var underforstået, at åbenbaringen på visse måder overskred menneskets fornuft og erkendelsesmuligheder. Ikke mindst den katekismusforklaring, faderen forfattede, peger i denne retning. I modsætning til de radikalere former for oplysningsteologi (fx neologi og rationalisme), der var mere tilbøjelige til at tilkende fornuften forrang i enhver henseende, forsøgte supranaturalisterne i realiteten at tage højde for den moderne oplysningsteologi og -filosofi, uden at det førte til en opgivelse af ortodoksiens overbevisning om Bibelens ufejlbarlighed og den rene lære, dvs. den lutherske dogmatik. ${ }^{4}$ På dansk grund finder man en tilsvarende teologisk orientering blandt ledende skikkelser i samtidens kirke- og undervisningsvæsen som Ove Høegh-Guldberg (1731-1808) og N. E. Balle (1744-1816), og i tysk sammenhæng bør nævnes den indflydelsesrige prædikant Franz Volkmar Reinhard (1753-1812). ${ }^{5}$

tionen rundt omkring i Europa i de enkelte lande, hvor landsherrens konfession efter princippet cujus regio, ejus religio gjordes til den eneste lovlige.

${ }^{2}$ En egentlig kortlægning af forudsætningerne for Grundtvigs Luthertolkning i $V K$ 1812 ville være for omfattende. En række forskellige studier (Michelsen 1954 og 1956, Aarnes 1961, Bugge 1965, Lundgreen-Nielsen 1980, Christensen 1998, Vind 1999) kommer på forskellig vis ind på nogle af disse forudsætninger.

${ }^{3}$ Billedet af disse barndomsmiljøer kunne tage flere nuancer med. Som K. E. Bugge har påvist (1965, 42-59), tilsluttede Johan Grundtvig sig eksempelvis visse af pietismens ideer om omvendelse osv. Desuden peger prædikenernes understregning af de gode gerninger mere mod en påvirkning fra pietisme og oplysning end mod ortodoksien. Til gengæld har Kingos salmer i begge hjem været dagligdag og foretrukne frem for Evangelisk-kristelig Psalmebog.

${ }^{4}$ Den væsentligste inspiration stammede især fra filosoffen Christian Wolff (1679-1754), men hen mod århundredeskiftet forsøgte man i stigende grad også at arbejde i forlængelse af kritiske opgør med den rene fornuft hos Immanuel Kant (1724-1804).

${ }^{5}$ Grundtvig udfærdigede et rosende mindedigt over Reinhard ved dennes død omtrent samtidig med færdiggørelsen af $V K$ 1812. Digtet blev trykt som indled- 
Hvor meget disse miljøer præcist har formet Grundtvig, kan selvfølgelig ikke afgøres med nogen sikkerhed, men at de har været væsentlige for hans forståelse af det, han var rundet af, kan der ikke herske tvivl om. I den omarbejdede dagbog fra 1804 beretter han fx om, hvordan han allerede i Thyregod-årene 1792-98 mødte den radikalere oplysning i forskellige tidsskrifter, men alligevel følte sig som "Orthodox" (US I, 15). Om denne selvopfattelse ændrede sig i latinskolen, beretter dagbogen ikke noget om. Til gengæld angiver Grundtvig, hvordan han i studieårene under sin læsning af den kontroversielle professor T. C. Bruuns Skriftemaal smerteligt havde følt, at han måtte opgive ortodoksien, som han selv kalder det. ${ }^{6}$ Ikke længe efter kritiseres flere af de centrale ortodokse dogmer, fx læren om den tilregnede retfærdighed (59-60), treenighedslæren og læren om Kristi to naturer (61), Der er tale om indvendinger, der alle synes præget af den nye oplysningsfilosofi, men som igen viser, hvor bevidst Grundtvig var om, hvorfra han kom. Derfor er det ikke overraskende, at Grundtvigs senere tilbagevenden til Udby har fordret en stillingtagen til netop denne baggrund.

Et lignede mønster kan registreres i Grundtvigs beskæftigelse med Luther selv $i$ årene frem til 1810. I sin undersøgelse af tilblivelsen af Grundtvigs historiesyn gør Michelsen meget ud af, at Grundtvig allerede i dagbogen hævder, at han allerede som barn i Udbytiden (dvs. inden han blev ni år) havde stiftet bekendtskab med Luther gennem Holbergs Kirkehistorie, Abraham Kalls verdenshistorie, Benjamin Lindners Lutherbiografi og desuden påbegyndt den obligatoriske katekismelæsning. Skønt Michelsen nok uddrager mere af dette, end der er belæg for, er det ikke usandsynligt, at Grundtvig herigennem tidligt har fået en række billeder af reformatoren, han siden hen kunne gøre brug af. I Thyregod og på latinskolen stiftede han desuden bekendtskab med Balles lærebog, HøeghGuldbergs Den Aabenbarede Theologie, Luthers store Katekismus og faderens katekismeforklaring. ${ }^{7}$ Desuden må man forestille sig - skønt det faktisk af hans skrifter er svært at udlede noget præcist om hans arbejde med Luther før 1810 - at Grundtvig i studieårene i København, i årene på Egeløkke og i perioden efter 1808, hvor han underviste i historie på det Schousboeske Institut, har været nødt til løbende at forholde sig til Luther.

Det egentligt betydningsfulde fra de år i forhold til den teologi og Luthertolkning, man finder efter 1810 og i $V K$ 1812, skal dog nok ikke søges så meget i selve arbejdet med Luther, men derimod i, at Grundtvig i kraft af sit møde med den romantiske filosofi stiftede bekendtskab med og begyndte at dyrke universalhistorie. Denne nye måde at forstå historien

ning til udgivelsen af prædikenen Hvorfor kaldes vi Lutheraner? (1812) og senere genoptrykt med få variationer i Kvcedlinger (1815) (US III, 98-103).

6 "proh dolor - Kaput var Ortodoxien" (US I, 25).

${ }^{7}$ Michelsen 1954, 49-181. 
på gjorde det muligt for ham at vende sig mod Luther uden at genoptage et stivnet dogmatisk læresystem, da hans hjemkomst som faderens kapellan i 1811 krævede, at han genovervejede det verdensbillede, han mente at have vendt ryggen. ${ }^{8}$

\section{$1810-1812$}

Det er velkendt, at forældrenes ønske om Grundtvigs tilbagevenden til Udby blev startskuddet til en ny tid med en række nye erkendelser, der i et vist omfang kan siges at kulminere i $V K$ 1812. Det gælder også forholdet til Luther. Mest bemærkelsesværdig var hans idé om en nært forstående reformation med ham selv i en hovedrolle. I et tilbageblik i Kirke-Speil beskriver han selv sin tankes opståen i efteråret 1810 på følgende vis:

Jeg husker godt endnu, hvordan det begyndte, thi jeg sad en Aften alene og læste i Kotzebues Historie af Prøjsen, som var den nyeste over dette Land, og som jeg, skjønt jeg dybt foragtede Navnet, mente som Lærer i Historien af Pligt at maatte benytte; men jeg var ikke kommen længere end til det trettende Aarhundrede, da de tyske Riddere indtog og med Sværdet kristnede Prøjsen, thi her havde Kotzebue plantet en af sine Giftblomster under, hvad han kaldte "det visne Kors"; og derved løb det mig koldt ned ad Ryggen, saa at jeg ikke blot smed Bogen fra mig, men sprang op som greben af en mægtig Aand, der kaldte mig til Reformator. Derpaa fulgte et Par Maaneder af stolt men stille Sværmeri, hvori jeg første Gang siden min Barndom for Alvor læste Bibelen, især Profeterne, Luthers og Kingos Salmer, bad og grublede over, hvordan en Reformation, især med Pen og Blæk, i vore Dage lod sig udføre. (US X, 341)

Det er svært at vide, hvor præcist dette tilbageblik gengiver Grundtvigs forestillinger fra det pågældende tidspunkt. En smule mere beskedent ser det $\mathrm{i}$ hvert fald ud i det lille fragment Lidet om Jesu Christi Aabenbaring ved Apostelen Johannes fra efteråret 1810, der fortolker apokalypsens syv menigheders engle som profetier om syv reformatorer i verdenshistorien. ${ }^{9}$ I denne udlægning er Luther den femte, mens Grundtvig selv blot er en forløber for den sjette. Grundtvigs overbevisning om selv at spille en rolle $i$ en kommende reformation kan dog næppe diskuteres. I fragmentet roses Luthers opgør med Paven, men Grundtvig kommer også ind på udsagnet til menigheden i Sardes om at leve, men dog være død (Åb 3,1). Dette kunne tolkes som Luthers ophold på Wartburg, indrømmer han, men finder det mere sandsynligt, at det er møntet på tiden siden Luther. Ved en

\footnotetext{
${ }^{8}$ Især på længere sigt syntes konsekvensen at blive en stadig mere bevidst afvisning af lutherdommens teologiske og samfundsmæssige doktriner som løsningen på samtidens problemer. Et nøgleeksempel er Skal den lutherske Reformation virkelig fortscettes? fra 1830 (US V, 278-354).

${ }^{9}$ Grundtvig-Studier 1956, 64-75.
} 
overdrevet forståelse af Luthers lære om gerninger har hans tilhængere nemlig fejlagtigt fået den opfattelse, at "de gode gerninger var skadelige for Saligheden", og derved er "både Tro og Gerning efter Skriften" forsvundet. Grundtvig ligger her tættere på pietismens eller rationalismens forståelse af gerninger end blot få måneder senere, men det vigtige på længere sigt lå i den principielle indrømmelse af muligheden for en udvikling hinsides lutherdommen, som skriftet i kraft af sin historieprofeti var udtryk for.

Allerede den 5. december kunne Grundtvig i et hyldestdigt $i$ anledning af faderens 50-års præstejubilæum give udtryk for en mere klassisk luthersk forståelse af gerningerne. ${ }^{10}$ Den gamle svage far hyldes således som en præst i Luthers ånd:

Fræk Du ei med Herren gik i Rette,

Vilde ei fortjene Himmerig,

Derfor Gud vil al Din Skyld udslette,

Salighed af Naade skænke Dig.

(US II, 48)

I de følgende strofer klandres samtiden for at gøre Luther til et lig uden ånd. Den mindesten, som skal udhugges til hans jubelfest, dvs. reformationsjubilæet 1817, vil lukke hans grav og dermed slå ham endegyldigt ihjel. Billedet minder om tanker fra et andet dokument, "Monumentum Lutheri," "11 sandsynligvis også fra Udby-tiden, hvor Grundtvig ligeledes forholder sig til den planlagte rejsning af et monument for Luther i Tyskland. I stedet for en intetsigende statue af reformatoren burde man rejse et monument over Kristi forsoning og læren om retfærdiggørelse ved tro eller simpelthen lade den reaktualiserede lære om retfærdiggørelsen være monumentet. Begge tekster peger på, hvordan Grundtvig i endnu højere grad end før årsskiftet på dette tidspunkt forsøgte at slå til lyd for en luthersk kristendom, samtiden var ved at glemme.

Det samme gør sig på anden vis gældende i et indlæg i K. L. Rahbeks ugeskrift Sandsigeren i april måned 1811, som ledsager en udgivelse af digtet "De hellige tre Konger ("Deilig er den Himmel blaa")". Indlægget består af nogle betragtninger om salmen som genre og modstiller de historisk-kristelige salmer fra lutherdommens første århundreder med salmerne i den nyeste salmebog, Evangelisk-kristelig Psalmebog fra 1798. De historiske salmer beskrives som en rindende bæk, hvorimod de "dogmatiske eller moralske" i den nuværende salmebog er som stillestående vande. Digterens begejstring over historiske skikkelser og deres gerninger er langt

\footnotetext{
${ }^{10}$ Digtet udkom med ændret strofisk forløb i digtsamlingen Nytaarsnat den 24. december 1810 .

${ }^{11}$ Fasc. 78.
} 
mere frugtbar end "den halvdøde lærende Fremstilling." Først og fremmest må Bibelen inddrages i salmedigtningen:

Maa nu enhver Kristen ansee Bibelen for et Indbegreb af Alt, hvad der troet og fulgt kan giøre os timelig og evig lyksalige, og tillige er sandere og høiere end Alt, hvad Mennesker kan optænke, saa følger heraf baade, at Bibelens Indhold maa være Sangenes, og at disse maa være digtede i hins Aand (US II, 78).

Grundtvig uddyber sin pointe ved at fastslå, at kirkesange (salmer) burde være levende billeder af "Jesu og de Hellige Mænds Liv" (78). Finder en tidsalders mennesker ikke længere behag i disse, er det et tegn på, at kristendommen ikke længere bor i deres hjerter. For de mange tusinder i Norden, som endnu ikke har bøjet knæ for tidens livløse afgudsbilleder, lover Grundtvig imidlertid en samling kristelige historiske sange, hvoraf en del skal forfattes af ham selv, men de fleste være gendigtninger af Kingo, Luther og ældre digtere. ${ }^{12}$ Få uger senere udnævntes Grundtvig til faderens kapellan i Udby og indsattes den 14. juni 1811 i embedet. ${ }^{13}$

De kommende 17 måneder inden udgivelse af $V K 1812$ fremfører Grundtvig i forskellige offentlige ytringer nogenlunde de samme takter som i foråret 1811. Her skal blot nævnes nogle få eksempler, der peger frem mod krøniken. I Nyeste Skilderie af Kjøbenhavn i august (LundgreenNielsen 1980, 473) imødegår han et forslag om at indføre Evangelisk-kristelig Psalmebog overalt som et slående udtryk for manglen på ægte lutherdom. Synspunktet er det samme som i Sandsigeren fra april. Til allehelgensdag 3. november finder man et 35-siders manuskript om Luther. Centralt står Luthers troskrise og retfærdiggørelseslæren. Desuden behandles Den Lille Katekismus og Luthers salmer. Manuskriptet som helhed viser stort indblik i Luthers liv og teologi. Det er sandsynligt, at Grundtvig allerede nu har haft og arbejdet med Walch-udgaven, som han henviser til en måned senere i en optegnelse. ${ }^{14}$ I digtsamlingen Saga, der udkommer ved årsskiftet 1811-12, ser man ligeledes en betoning af lutherdommens centrale betydning i historien og endvidere i digtet Roskilde fra sommeren

12 Som Lundgreen-Nielsen bemærker, ligger synpunktet helt i forlængelse af Grundtvigs fars mening om den nye salmebog, som Balle havde sendt ham et prøveeksemplar af i 1793 (Fasc. 551; Lundgreen-Nielsen 1980, 899).

${ }^{13}$ Fra omtrent samme tid stammer et ikke udgivet Rimbrev, hvor Grundtvig atter tilslutter sig den lutherske opfattelse af Guds alenevirken i nåden (Albeck 1955, 92-95).

${ }^{14}$ Fasc. 148.15. I registranten angives, at man ikke kan finde henvisningen til Lutherudgaven, idet man har troet, det er en dansk udgave (Bugge 1965, 162). 
$1812,{ }^{15}$ der er bygget op som en rejse ad Isefjorden ind i Roskilde Domkirke, men samtidig er en symbolsk tidsrejse fyldt med historiske referencer. I digtet ses Luther som årsagen til, at kristendommen overlevede. Kort inden årsskiftet udkom $V K 1812$.

\section{Fortalen i $V K 1812$}

I fortalen videreføres Lutherbilledet fra de foregående år. Den begynder med nogle siders let redigerede uddrag fra andet bind af Tyge Rothes fortale til bogen Christendommens Virkning paa Folkenes Tilstand i Europa (1775). I disse gives udtryk for, at det at filosofere over historien uden inddragelse af en Gudsforestilling er et labyrintisk, kaotisk og rædselsvækkende foretagende. Det gøres alt for ofte og ender som en gengivelse af menneskenes planløse frie handlinger med forskellige og modsatrettede hensigter. Mange efterlades heraf i tvivl og kan ikke finde deres Gud "eller hans Vældes, hans Godheds Fodspor, eller hans Tilsyns og Styrelses Mærker" (US II, 172). Rothe hævder imidlertid, at han i historien i og imellem menneskenes handlinger har skuet en linje eller kæde, der viser Guds plan. Kunsten er at øjne den gode Gud i verdensbegivenhedernes udvikling. Bogen er således en "historisk Theodice" (175), der skal vise den skjulte Guds fodspor i Verden.

Ikke overraskende tilslutter Grundtvig sig Rothes anliggende som sammenfaldende med sit eget, men spår, at hans verdenskrønike derfor ligesom Rothes bog hurtigt vil blive glemt. Rothes ord fremhæves i modsætning til de vise mestre og deres skriftfortolkninger (formentlig en hentydning til samtidens førende forskere i bibelsk eksegese). Det afgørende er at forstå, at der består en tæt sammenhæng mellem et folks tro og dets bedrifter, hævder Grundtvig. Gerninger er en virkning af menneskers tankegang og er derfor til syvende og sidst, hvor der findes kristendom, bestemt af det usynlige Gudsforankrede uegennyttige kærlighedsliv. Endvidere hænger tro og sandhedserkendelse tæt sammen: "Er der nemlig en Gud, da maa Hans Forsyns Spor og være i Tiden, udgik Jesus fra Faderen i Tidens Fylde, da maa de forrige Tider henvise til ham" (179).

Med en allusion til Åbenbaringen 3,7 hævder Grundtvig, at Gud selv har skænket os "den Davidsnøgel, som oplader Dørren, Ingen mer kan tillukke: den hemmelige Dør til Krønikens Helligdom" (180). Uden denne nøgle må alt tumle efter tilfældets luner. Men ved at se ind i helligdommen, altså historien, står udfaldet skrevet på muren med hemmelige stave. Strukturelt svarer tekstens begreb om læsningen af historien til Lu-

\footnotetext{
${ }^{15}$ Fasc. 400. Grundtvig oplæste digtet på Roskilde landemode i oktober 1812. Det er aldrig trykt i sin oprindelige helhed. Fasc. 401 er en renskrift ved Svend Grundtvig, dog uden hensyntagen til overstregede verslinjer.
} 
thers tanke om læsningen af skriften som et ydre ord (verbum externum). Der er næppe tvivl om, at Grundtvig selv opfatter det sådan.

Det er også på dette sted i forordet, at Luther nævnes. Skønt håbet er det modsatte, gør Grundtvig opmærksom på, at bogen sikkert vil fortørne og forbitre mange. Havde han, som det først var planen, skrevet kun om de almindelige begivenheder med vink om deres indbyrdes sammenhæng, ville han oven i købet have leveret en passende ledetråd til undervisningsbrug. Men som han havde nærmet sig Luther, blev det en trang for ham at vise, hvad Gud udrettede ved ham, men også hvad der var forspildt i tidens løb, hvordan det gik til grunde, og hvad man kunne forvente af fremtiden. Han måtte derfor udvide fremstillingen og gå ind i tidsrummets irgange og beskrive selv de mindste sener, nerver og hjerteslag i tidens kæmpelegeme.

I den sidste del af fortalen ønsker Grundtvig, at læseren ikke vil sammenblande hans omtvistelige meninger om mænd og folkefærds herkomst eller om menneskelige åndsytringer med hans udsagn om forsyn, tro og kristendom, som er den åbenbare sandhed. Læseren kan kun være uenig med ham om det, han selv kan have fundet på. Resten bekræfter Guds egne ord, skriften. Hvordan en sådan læsning i praksis skal kunne lade sig gøre, giver han ingen opskrift på.

Endvidere bekender Grundtvig sin gæld til Steffens, der ved sine forelæsninger havde givet ham "Ideen om Tidernes Sammenhæng og Kristus i deres Middelpunkt" (184). ${ }^{16}$ Denne universalhistoriske anskuelsesform fandt han senere bekræftet i mødet med Schiller. ${ }^{17}$ Desuden nævner Grundtvig Friedrich Schlegel, der havde lært ham at skelne mellem lutheranere og Calvinister. ${ }^{18}$ Den største læremester er dog Gud selv.

Afslutningsvis forudses, at man vil kalde bogen en "Paskvil", altså et smædeskrift, men dette må så i Guds navn få være, for han kan ikke andet. Lundgreen-Nielsen bemærker, at der måske kunne være tale om en reminiscens af Luthers ord i Worms (Lundgreen-Nielsen 1980, 547). Uanset hvad føler Grundtvig sig på sikker luthersk grund, idet han "om de nærværende og som om de forbigangne Mænd og Tider har udsagt

16 Det sidste er måske en hentydning til den lutherske idé om Kristus som skriftens midte. Denne fortolkning sandsynliggøres af, at Grundtvig i vidt omfang i resten af $V K 1812$ opfatter Luthers udlægning af Biblen og sin egen udlægning af historien som to sider af samme sag.

${ }^{17}$ Grundtvig refererer formodentlig til, at han oversatte et udtog af Schillers Was heisst und zu welchem Ende studiert man Universalgeschichte i 1806. Se: Albeck 1979, 275-278.

${ }^{18}$ Friedrich Schlegel: Ueber die neuere Geschichte. Vorlesungen gehalten zu Wien im Jahre 1810 (1810). Det drejer sig formentlig især om den senere sondring, Grundtvig i VK 1812 foretager mellem Calvins brug af forstand og Luthers poetiske sans. 
Bibelens Dom" (US II, 185). Hvad det vil sige, er der dog foreløbigt ikke givet svar på.

\section{Luthertolkningen i reformationsafsnittet}

VK 1812 er skævt disponeret. "Femte Tidsrum - Fra Luther til Sydamerikas Opstand" fylder over dobbelt så meget som de forudgående tidsrum tilsammen. Begivenhederne skildres derfor også langt mere detaljeret end tidligere. Det er ikke tilfældigt. Grundtvig tolker den forudgående verdenshistorie som et forløb, der bygger op til Luthers ankomst, et højdepunkt i kristendommens udvikling. ${ }^{19}$ Fjerde hovedafsnit ender med, at pavedømmets vildfarelser og afladshandelen - som end ikke renæssancehumanismen formår at rette op på - gør behovet for Guds indgriben nødvendigt.

Reformationsafsnittet begynder med det nye universitet i Wittenberg. Landsherrerne forsøgte at samle dygtige mænd, der kunne give stedet et godt ry. Grundtvig tolker det som en del af forsynet. Det, ingen tænkte på, var, at "Gud herved rundt fra Tyskland forsamlede de Mænd, der skulle udføre hans store Værk, Kristendommens Genfødelse" (249).

Blandt de store navne, der fik studenterne til at strømme til, fremhæves især Luther og Melanchthon. Luther havde allerede udmærket sig i tiden ved universitetet i Erfurt, men var herefter af bekymring for sin sjæls frelse draget i augustinerkloster. Her visnede han dog "som en saftløs Urt" ved den udvortes spægelse og den indvortes anfægtelse. Men Gud ledte ham til nåden ved troen på Kristi død og gjorde ham stærk. Med Kristus som forbillede kom han ud af det snævre munkebur. Præst var han allerede, men han kaldtes nu også til professor i filosofi i Wittenberg.

Melanchthon havde ikke som Luther tilkæmpet sig troens dyrebare klenodie. Han kunne derfor ikke elske det så højt eller stride så mandigt for det. Grundtvig sammenligner hans ydmyge sind med stillestående vand, der spejler solen, men frygter stormen. Han kunne imidlertid støtte sig til Luther, så længe denne levede. Melanchthons fortjeneste var, at han "udtolkede Luthers høie Taler for de Umyndige" (250), og skønt han som enhver tolk af og til tog fejl, lykkedes det ham derved som regel at gengive meningen med Luthers dristige udtryksfulde ord i en klar form, som modstanderne ikke så let kunne fordreje. Man ser altså her, hvordan Grundtvig helt korrekt opfatter Melanchthon som strategen og den, der i praksis kunne formulere og drage konsekvenser af Luthers tanker.

Men allerede inden Melanchthon kom til Wittenberg, var "Aanden udfaret i Storm for at rense den kvalme Luft og bevæge de stinkende Vande" (250). Grundtvig fremhæver Luthers opgør med afladshandelen og sammenhængen med erkendelsen af, at kun troen på og tilegnelsen af

${ }^{19}$ Med Lundgreen-Nielsens ord: "Idémæssigt er Kristus værkets centrum, handlingsmæssigt Luther” (1980, 549) 
Kristi pine og død kunne skaffe syndsforladelse og nåde. Det er tydeligt, at Grundtvig ikke længere er i tvivl om rigtigheden af Luthers forstålse af retfærdighed. I den efterfølgende kamp "med Mund og Pen" kunne fjenderne ikke klare sig mod den ånd og visdom, han talte med, og måtte i stedet ty til bål og sværd. Dog glemte de, at de ikke havde anden magt end den, der blev dem givet ovenfra. "De udvortes Omstændigheder maatte da føie sig derefter og alle Ting tjene Ham til Gode, som elskede Gud, og var kaldt efter et evigt Forsæt til at rense den besmittede Helligdom" (250). Udlægningen af forløbet er tydeligt farvet af bogens overordnede forståelse af Luther som et redskab i Guds hånd og reformationen som et udtryk for Guds mening med udviklingen.

Derpå skildres kurfyrst Frederik den Vises vanskeligheder ved at beskytte Luther. Passagen vidner om stor indsigt i, hvor svært det var at forholde sig til kejser Karl V, der beskrives som tvetunget og tvesindet og helt styret af ønsket om magt. Grundtvig gør det klart, at afladshandelen langtfra var det eneste, Luther bestred, da han vendte tilbage fra Wartburg til Wittenberg. Han peger især på Luthers forståelse af skriften. Alt, der ikke byggede på tydelige ord i skriften, forkastede han som løgn og vildfarelse. Desuden udlagde han ved Guds og venners hjælp Bibelen på tysk og med en sådan enfoldig kløgt og kraft, at selv de vantro, der har forstand på skriften (de moderne eksegeter?), må sande, at det for sin tid var et mageløst værk. Indholdet af Luthers skriftfortolkning karakteriseres derpå kort:

Den synderligste [mest scerprcegede] Deel og ligesom Hovedet af hans Lære, var, at Mennesket formedelst Adams Synd var blevet uduelig til at opfylde Loven, som befaler at elske Gud over alle Ting og Næsten som sig selv, men at Kristus havde opfyldt den i vort Sted, og baaret Syndens fortjende Straf; at ham er givet al Magt baade i Himlen og paa Jorden, og at han er vor eneste Talsmand hos Faderen (US II, 251).

Eftersom dette var Luthers udlægning af Bibelen, må Grundtvig mene, at dette i realiteten er prøvestenen for sand og falsk kristendom. Han redegør på den baggrund for sin opfattelse af årsagerne til Luthers afvisning af de misbrug, som havde udviklet sig i Romerkirken. Luthers Bibellæsning førte til, anfører Grundtvig, at han måtte forkaste ikke bare troen på pavens ufejlbarlighed, men alle menneskebud i trossager. Næst efter afladen og læren om fortjenstfulde gerninger var de værste vildfarelser for Luther helgendyrkelse, læren om skærsilden og munkelivets hellighed.

Grundtvigs udlægning bærer tydeligt præg af Luthers egen opfattelse af udviklingen. Helgendyrkelsen havde med tiden udviklet sig til afguderi. Læren om skærsilden var blevet til i takt med, at troen på Kristi forsoning blev svagere. Også her er hans opfattelse klassisk. Da man begyndte at tro på de gode gerninger, måtte læren ændres til, at det kun var syndere, der behøvede renselsen, som nu blev en straf, men også en trøst, da skærs- 
ilden ikke ville vare evigt. Dette blev baggrund for udviklingen af sjælemesser og under pave Leo X til salg af aflad for levende og døde. Da munkevæsenet er blevet behandlet i de tidligere kapitler, afstår Grundtvig fra endnu en gennemgang. Nonneklostrene kritiseres til gengæld for at være en slags fængsler, hvor Gud bespottedes omtrent lige så meget "ved den hyklede Andagt, som ved de der herskende Synder" (253).

Efter således at have haft nærmest fuld sympati med reformationen som en nødvendig kirkelig og kulturel forandring af samfundet i det 16. århundrede skifter Grundtvig nu til et mere kritisk blik på konsekvenserne af reformationen. Mange, der ikke bekymrede sig om sjæl eller salighed, greb i den omskiftelige tid lejligheden til at afkaste det gejstlige åg, hævder Grundtvig. Især fyrster og adelsfolk så store fordele i at bifalde den nye lære, idet den for dem ofte betød personlig magt og rigdom. Der var dog også problemer. Hvor Gud bygger en kirke, rejser Satan fluks en synagoge, havde Luther sagt, og det havde historien vist var sandt. Grundtvig tænker på sværmerne og nævner Müntzer, Karlstadt, Schwenckfeld og Paracelsus. Fælles for disse var, at de under den store gæring (reformationstiden) forvekslede den nye åndelige frihed med borgerlig frihed og retten til hævn og oprør. Luthers fortjeneste over for disse var at holde fast i Guds skrevne ord. Grundtvig tolker denne vægt på ordet som en hovedårsag til reformationens forløb.

På dette sted i den refererede sammenhæng gør Grundtvig imidlertid en interessant iagttagelse, der viser, at han ser en snæver sammenhæng mellem konfessioner og kulturdannelse i de enkelte lande i kejserriget: "I de øvrige Lande, hvor Forstanden var Hjertets Overherre, forargedes Man snart over Luthers Kamp for Bibelens hemmelige Tale om Kristus, som er Fornuften en Daarlighed, og tyktes bedre om den Røst, som fra Schveits lod sig høre" (254). Røsten er naturligvis Zwinglis. Den store forskel på Luther og Zwingli var, påstår Grundtvig, at Zwingli "manglede hardtad al Poesi" (254). Derfor ønskede han modsat Luther at finde så få hemmeligheder i Bibelen som muligt, nægtede Kristi virkelige nærværelse i nadveren og gav forstanden for meget råderum i udlægningen af de hellige skrifter. I grunden finder Grundtvig Zwinglis teologi selvmodsigende og ser det som årsagen til, at hans tilhængere delte sig mellem dem, der blev sværmere og påberåbte sig Helligåndens gaver, og de vantro, der påberåbte sig deres forstand.

Omtalen af Calvin følger samme spor. Han og de reformerte blev langt mere forhadte i den gamle kirke, altså romerkirken, end de lutherske. Deres lære om nadveren, forkastelsen af alle kirkeskikke og al gejstlig øvrighed stod i mere radikal modsætning til katolicismen. Grundtvig tilskriver det atter den "kolde Forstandighed". Troen på værdien af egen forstand som indgivet af Gud er også det, der har præget de reformertes forhold til det borgerlige liv. Derfor har de ikke afskyet ond handel 
eller oprør og deres sindelag forhindret dem i at tænke ukærligt mod enhver, som tænker anderledes, anføres det.

Helt forskelligt herfra må man betragte Luther: "For Luther var Bibelen det Første og det Sidste, villig bøiede han sig under dens Myndighed og med Digterøie beskuede han de høie Hemmeligheder som i et Speil. Hans Oversættelse af Bibelen og hans Kirkesange ere hans Poesies varige Mindesmærker" (255). Det er altså ikke - som hos de reformerte brug af forstanden, der gennemsyrer den lutherske tolkning af Biblen og Luthers salmedigtning, men tværtimod blikket for det jordiskes evne til at spejle det himmelske i et dunkelt, hemmelighedsfuldt og endnu ikke afklaret lys. Som Aarnes har gjort opmærksom på, supplerer Grundtvig herved i VK 1812 en teologisk tolkning af forskellen på reformatorerne med en romantisk, ${ }^{20}$ men foregriber samtidig også Danne-Virke-årenes brug af spejlet $(1$ Kor 13,12) som metafor for menneskets ikke fuldt udviklede erkendelsesevne.

Bibelen blev for de ægte lutheranere en "Prøvesteen" (256) mod al grublen og sværmeri, anfører Grundtvig. Det vil sige, Bibelen blev et sted at henvende sig med sin tvivl om, hvordan man får øje på den sande kristendom i historie og nutid. Synspunktet bliver anledning til udfoldelsen af en mindre kulturteori. Hører man, som lutheranerne, Guds stemme i det ydre ord (verbum externum), bliver man åben over for, hvad der kan tjene til opbyggelse. I modsætning til den foregående karakteristik af de reformerte, som følger deres egen forstand, hører lutheranerne Guds ord netop som et ydre ord. De foragter derfor heller ikke kirkekunst, musik og salmer, for de vil, at jorden fyldes af Guds tilbedelse, og de ønsker at lære bibelske sprog og efterspore Guds husholdning i de gamle dage (historien) og i hans store gård (Jorden), da de ved, at han på intet tidspunkt og på intet sted har ladet sig selv uden vidnesbyrd. Fortolkningen af den lutherske indstilling minder om det, der i fortalen angives som hele meningen med bogen, nemlig at tolke Guds forsyns spor. Som sådan er det tydeligt, at Grundtvig betragter sin fremstilling som udløst af lutherdommen. Det at studere kræver i virkeligheden den åbenhed, som ligger i arven fra Luther.

Alligevel synes denne universalhistoriske måde at tænke på at ligge meget langt fra noget, der med rimelighed kan betegnes som luthersk ortodoksi. Når Bibelen skal dømme historien, handler det om, at en bestemt læsning af den som helhed og med Kristus som "Middelpunkt" følges som udslagsgivende for en bestemmelse af, hvor der i historien har været kristendom og hvor ikke. I VK 1812 er den væsentligste ambition ikke at påvise de enkelte bogstavers holdbarhed eller at bygge et dogmatisk system op.

${ }^{20}$ Aarnes 1983, 60. 
De borgerlige konsekvenser af skriftfortolkningen er anderledes for de lutherske end for sværmerne og de reformerte, anføres det. Lutheranerne er gode til at tage vare på embeder, sætte livet på spil for deres brødre og at indrette sig under den verdslige myndighed, der jo af Luther betragtes som indstiftet af Gud. Disse sondringer mellem reformationens forskellige retningers udgangspunkt bliver i resten af fremstillingen tydeligt bestemmende for Grundtvigs vurderinger af den verdenshistoriske udvikling. ${ }^{21}$

Men det er bestemt ikke kun et glansbillede af den lutherske menighed, der tegnes. Alle vegne savner den senere udvikling meget i sammenligning med det idealbillede af kirken og dens liv, man finder hos Luther. Grundtrækkene var der, så længe Luther levede, men herefter gik det galt, sådan som Luther selv havde forudset. Skiftet kommer, da Melanchthon efter Luthers død og den schmalkaldiske krig underskriver Interim og derved lider et tillidstab blandt Luthers disciple. Melanchthon var en ven af Aristoteles og lige saa ræd, som Luther var djærv, hævder Grundtvig. Det fik konsekvenser for hans lære, der trak i reformert retning:

\begin{abstract}
Melanchton var i Grunden af Zvingels Mening om Nadveren, og hans Tale saavel om Menneskets egne Kræfter, som om gode Gerninger kunde let ryste Forsoningslæren. Hos ham selv havde det vel ingen Fare, og hans Iver for Lovens Prædiken reiste sig vist mest af den Bedrøvelse, hvormed han saae Mange synde sikkert og kun Faa handle, som Luther, af Troens og Hjertets Fylde; men saasnart vi lægge mindste Vegt paa vor egen Størke og vore gode Gerninger, er Hovmoden tilrede og Troen i Fare (US II, 292293).
\end{abstract}

Grundtvig betoner, at Luthers anliggende slet ikke var nok til at udlede en ny lære, men at han simpelthen talte ud af sine erfaringer med hovmod og tro. Man kan heller ikke sige, at han "dyssede Folk i Søvn" (293) med evangeliet. Han hadede spidsfindigheder og vejede derfor ikke altid sine ord så nøje. Således var det også med hans tilhængere. Melanchthons disciple derimod kløvede ord. Derved udbrød tvisten om arvesynd og gode gerninger, som nok også hang sammen med, at man måtte dyrke ordkløveri for at kunne bekæmpe jesuitterne med deres egne våben. Alt dette "maatte nødvendig føre bort fra Bibelen, fra Sprogenes grundige Dyrkning og al ret Videnskab". Det er tydeligt, at Grundtvig i resten af 1812-krøniken er af den opfattelse, at man aldrig rigtig er kommet sig over dette. Skønt Grundtvig senere finder "den sidste herlige Genlyd af Luthersk Poesi" hos Paul Gerhardt (1607-76), er og bliver Luther selv det foreløbige højdepunkt i verdenshistoriens udvikling.

\footnotetext{
${ }^{21}$ Sondringerne kunne være prægede af Fr. Schlegel, jf. fortalens henvisning til dennes Wien-forelæsninger (US II, 185).
} 


\section{Afslutning}

Den unge Grundtvig er ofte blevet beskyldt for at være en ortodoks lutheraner, ${ }^{22}$ og uden præcision er årene 1812-15 blevet kaldt Grundtvigs bibelkristne periode ${ }^{23}$ Hvis der med ortodoks sigtes til den kultur, han var vokset op i, eller den kirkelige og teologiske periode i kirkehistorien, man almindeligvis kalder ortodoksien, kan det på baggrund af den forudgående periodes hovedværk VK 1812 ikke bekræftes. Reformationen og det verdenshistoriske forløb fortolkes ved hjælp af en særlig sammensmeltning af forsynstro, universalhistorie og teologi, og nok er Bibelen en form for prøvesten, men det vil sige Bibelen samlet fortolket og især efter Luther med Kristus og retfærdiggørelsesforståelsen i centrum. Ud over, at fremstillingen begynder med skabelsen og anvender 1 Mos 1-3 som kilde til historien, er ønsket om påvise de bibelske udsagn ud fra en inspirationslære eller lignende ikke synderligt fremtrædende, og det kan ikke siges at være en hensigt med løsrevne bibelsteder som grundlag at udlede en systematisk sammenhængende dogmatik. Når Bibelen er vigtig som målestok for historien, skyldes det først og fremmest, at den viser hen til den sande kristendom. Her lægger Grundtvigs fortolkninger sig meget tæt op ad Luthers, og han ser Luther som det mest udviklede udtryk for sand kristendom, Gud endnu har frembragt i historien. Er Kristus middelpunkt, altså et åndeligt centrum i historien, er Luther det foreløbige højdepunkt i udviklingen, universalhistorisk betragtet. Det ses helt utvetydigt $i$ hans afvisning af sværmerne, de reformerte og $i$ hans påpegning af fejlene hos Melanchthon og i udviklingen af den lutherske tradition og endelig til sidst også $\mathrm{i}$ hans vurdering af den nyere filosofi.

Det eneste, Grundtvig bebrejder Luther, er hans karske sprog, der er blevet årsag til mange misforståelser. Det er dog ikke i virkeligheden nogen kritik. Grundvigs forbehold over for lærestridighederne mellem Luthers og Melanchthons disciple, der mundede ud i ortodoksien, beror netop på det synspunkt, at erfaring og karskhed er at foretrække frem for ordkløveri, og at lærebygninger har stillet sig i vejen for kristendommens sande ånd. Historien bliver for Grundtvig en slags ydre ord (verbum externum) sammen med Bibelen, en vej til sandhedserkendelse, ja, på en måde er Bibelen i den forstand for Grundtvig allerede i 1812-krøniken det, han siden selv kaldte en "Oplysnings-Bog". ${ }^{24}$

\footnotetext{
${ }^{22}$ Fx Korsgaard 2004, 48.

${ }^{23}$ Lige siden Begtrup (1900).

${ }^{24}$ Fx US V, 325 og US VIII, 553.
} 